\title{
A Contribution to the Knowledge of Vascular Flora of the Site of Biological and Ecological Interest of Kharouba in the Central Plateau of Morocco
}

\author{
Dallahi Youssef \\ El Aboudi Ahmed \\ Laboratoire de botanique, mycologie et environnement, \\ département de biologie, Faculté des Sciences, Rabat-Agdal, Maroc. \\ Aafi Abderrahman \\ École Nationale Forestière d’Ingénieurs, Salé - Maroc.
}

doi: 10.19044/esj.2016.v12n27p358 URL:http://dx.doi.org/10.19044/esj.2016.v12n27p358

\begin{abstract}
The current study aims to quantify and evaluate the Tetraclinis stands (Tetraclinis articulata (Vahl.) Masters) richness and floristic diversity at Kharouba Site of Biological and Ecological Interest (SBEI).

The 150 floristic surveys conducted in the site allowed us to inventory 143 species distinguished with rare taxa majority that are distributed over 54 families and 123 genera. This reduced number of taxa reflects the alarming biodiversity deterioration of the SBEI.

The study also enabled us to define the biological spectrum of the study area that is characterized by a significant abundance of Therophytes.
\end{abstract}

Keywords: floristic richness, biodiversity, ecosystem, Tetraclinis, Morocco.

\section{Introduction}

Due to its typical geographical position between the Atlantic to the West and in the Mediterranean Sea to the North, Morocco remains among the most biodiversity-rich Mediterranean countries in terms of floristic diversity. Indeed, the Moroccan flora currently about 4500 species and subspecies with 940 genera and 135 families (Benabid, 2000).

The Site of Biological and Ecological Interest (SBEI) of Kharouba, located in the central part of the Moroccan Central Plateau, home to relatively conserved and beautiful Tetraclinis stands, is characterized by an important floristic richness. However, these unique floristic aspects are still little known and the studies carried out on the area are limited.

Therefore, this study aims to quantify and characterize the floristic richness and diversity of the SBEI, in order to improve the common 
knowledge for sustainable management of the Tetraclinis articulata ecosystem in the Moroccan Central Plateau.

\section{Method and materials}

The SBEI of Kharouba (Figure 1), covering an area of 6300 hectares, is a one priority site (AFM, 1996). This biological site, located in the Moroccan Central Plateau, is distinguished by its mountainous reliefs, rugged nature and the abundance of Ordovician rocks represented by various schists including slate, sandstone and quartzite. The soil in the region is mostly skeletal. The local climate is marked by moderate annual rainfall between $450 \mathrm{~mm}$ and $600 \mathrm{~mm}$ and the average annual temperature varies from $1{ }^{\circ} \mathrm{C}$ to $34{ }^{\circ} \mathrm{C}$. The bioclimate as subhumid and semi-arid with temperate and cool variants (MCEF, 2002).

This SBEI is dominated by Tetraclinis stands growing in low altitude and in warm zones and the Quercus rotundifolia in the areas relatively better watered and humid (AFM, 1996).

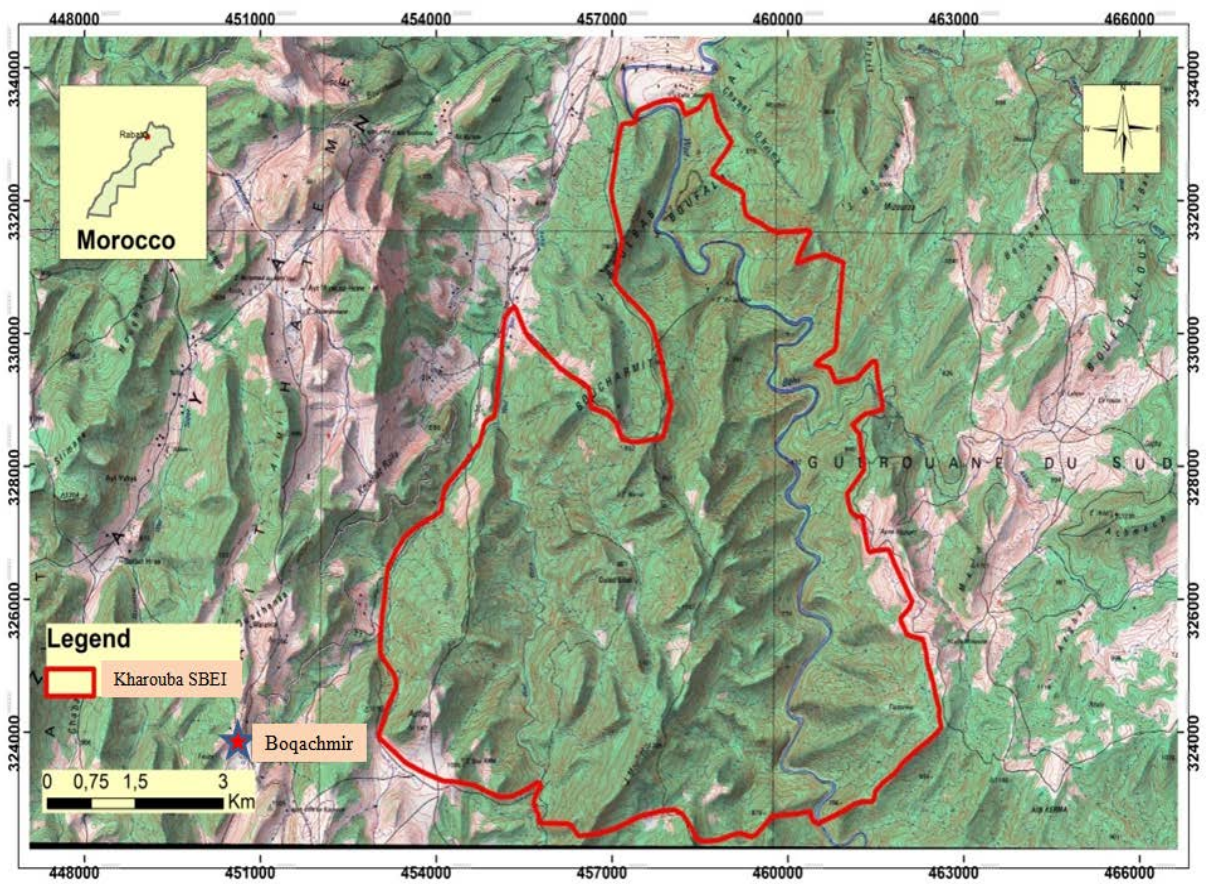

Fig 1: Kharouba SBEI location Map

During 3 months (March, April and May 2013), 150 floristic surveys were conducted in the different plant formations, based on the physionomical features, height and cover of the different plant formations and according to the altitude, exposure, soil, slope and substrate parameters. 
For each station, an exhaustive floristic inventory was carried out adopting the quantitative method developed by Braun-Blanquet et al. (1932) which is found on the abundance-dominance and sociability indexes.

In order to standardize the floristic lists, species nomenclature was determined using several flora and contributions of which we quote:

- The international Code of Nomenclature for algae, fungi, and plants (Melbourne Code) endorsed by the Eighteenth International Botanical Congress, Melbourne (McNeill et al. 2012);

- The nomenclature of higher plants according to Flora Europaea (Tutin et al. 1964- 1980) and Medchecklist (Greuter et al. 1984, 1986) for the vascular plants of the circum-mediterranean countries;

- The Catalogue of the Plants of Morocco (Jahandiez \& Maire, 19311934) for Moroccain special species.

\section{Results}

The data compilation and analysis of the floristic surveys conducted in the field has allowed us to elaborate this catalogue. Likewise, these taxa are classified by family, very rare taxa in the SBEI (TR), rare taxa (R), abundant taxa (A) and very abundant taxa (TA).

Vascular flora of the Site of Biological and Ecological Interest Site of Kharouba 
Adoxaceae

Viburnum tinus L. (R)

Amaranthaceae

Atriplex halimus L. (TR)

Amaryllidaceae

Allium pallens L. (TR)

Anacardiaceae

Pistacia atlantica Desf. (R)

Pistacia lentiscus L. (TA)

Rhus pentaphylla (Jacq.) Desf. (R)

Apiaceae

Ammi majus L. (TA)

Bupleurum semicompositum L. (TR)

Daucus carota L. subsp. Carota (TA)

Eryngium tenue Lam. (R)

Eryngium tricuspedatum L. (TA)

Eryngium triquetrum Vahl. (R)

Smyrnium olusatrum L. (TR)

Apocynaceae

Caralluma europaea (Guss.) N.E.Br. (R)

Nerium oleander L. (R)

Araceae

Arisarum vulgare Targ.Tozz. (R)

Arecaceae

Chamaerops humilis L. (TR)

Asparagaceae

Asparagus albus L. (R)

Asparagus altissimus L. (R)

Asteraceae

Atractylis cancellata L. (A)

Carduus marianus L. (A)

Carlina racemosa L. (R)

Cirsium acarna (L.) Moench. (A)

Cynara hystrix Ball. (TR)

Echinops spinosus L. (TR)

Evax pygmaea (L.) Brot. (A)

Filago germanica L. (R)

Hyoseris radiata L. (TR)

Leontodon hispidus L. (A)

Leontodon saxatilis Lamk. (R)

Leontodon tuberosus L. (TR)

Logfia gallica (L.) Coss. \& Germ. (A)

Ormenis mixta (L.) Dumort. (TA)

Phagnalon saxatile (L.) Cass. (A)

Pulicaria odora (L.) Rchb. (TR)

Scolymus hispanicus L. (TR)

Senecio vulgaris L. (TR)

Silybum marianum (L.) Gaertn. (TR)

Sonchus asper (L.) Hill. (TA)

Sonchus oleraceus L. (TR)
Taraxacum officinale Weber. (R)

Tolpis barbata (L.) Gaertn. (TR)

Boraginaceae

Anchusa azurea Mill. (R)

Brassicaceae

Biscutella didyma L. (R)

Diplotaxis catholica (L.) DC. (R)

Campanulaceae

Campanula dichotoma L. (R)

Caprifoliaceae

Knautia arvensis (L.) Coult. (TR)

Lonicera arborea Boiss. (TR)

Lonicera implexa Aiton. (TR)

Caryophyllaceae

Cerastium dichotomum L. (TR)

Cerastium glaucum Gren. (TR)

Cerastium glomeratum Thuill. (TR)

Paronychia argentea Lamk. (TR)

Spergula arvensis L. (TR)

Cistaceae

Cistus albidus L. (TA)

Cistus salviifolius L. (A)

Cistus villosus L. (TR)

Convolvulaceae

Convolvulus siculus L. (TR)

Crassulaceae

Sedum sediforme (Jacq.) Pau. (TR)

Umbilicus rupestris (Salisbury)

Dandy.(TR)

Cucurbitaceae

Bryonia dioica Jacq. (TR)

Cupressaceae

Tetraclinis articulata (Vahl.) Masters.

(TA)

Dioscoreaceae

Tamus communis L. (R)

Dipsacaceae

Dipsacus sativus (L.) Honck. (R)

Ephedraceae

Ephedra fragilis Desf. (TR)

Ericaceae

Arbutus unedo L. (A)

Euphorbiaceae

Mercurialis annua L. (R)

Fabaceae

Anthyllis tetraphylla L. (A)

Ceratonia siliqua L. (A)

Coronilla scorpioides (L.) Koch. (R)

Coronilla viminalis Salisb. (TR)

Cytisus triflorus Lam. (TR) 
Lotus arenarius Brot. (TR)

Lotus corniculatus L. (TR)

Medicago hispida Gaertn. (TA)

Ononis natrix L. (R)

Sarothamnus arboreus (Desf.) Webb (R)

Scorpiurus muricatus L. (TR)

Trifolium stellatum L. (TA)

Vicia tenuifolia Roth. (R)

Fagaceae

Quercus rotundifolia Lam. (TA)

Gentianaceae

Centaurium erythraea Rafn. (TR)

Geraniaceae

Erodium bipinnatum Willd. (TR)

Geranium molle L. (A)

Lamiaceae

Lamium flexuosum Ten. (TR)

Lavandula multifida L. (A)

Lavandula stoechas L. (A)

Teucrium fruticans L. (R)

Liliaceae

Asphodelus microcarpus Salzm. \& Viv

(TA)

Urginea maritima (L.) Baker (A)

Linum strictum L. (TR)

Malvaceae

Malva sylvestris L. (TR)

Lavatera trimestris L. (A)

Moraceae

Ficus carica L. (TR)

Myrtaceae

Myrtus communis L. (TR)

Oleaceae

Jasminum fruticans L. (TA)

Olea europaea L. var. oleaster (TA)

Phillyrea angustifolia L. (A)

Phillyrea latifolia L. (TA)

Papaveraceae

Fumaria macrosepala Boiss. (TR)

Papaver rhoeas L. (TR)

Plantaginaceae

Globularia alypum L. (TR)

Plantago lanceolata L. (A)

Plantago ovata Forsk. (TR)

Plantago psyllium L. (R)

Plumbaginaceae

Limonium sinuatum (L.)MILLER (TR)

Poaceae

Aegilops ovata L. (TR)

Anthoxanthum odoratum L. (TR)
Arundo donax L. (TR)

Avena sterilis L. (R)

Briza maxima L. (R)

Bromus hordeaceus L. (TA)

Bromus rubens L. (TR)

Cynodon dactylon (L.) Pers. (R)

Cynosurus elegans Desf. (TR)

Dactylis glomerata L. (R)

Festuca coerulescens Desf. (TR)

Hyparrhenia hirta (L.) Stapf. (R)

Lamarckia aurea (L.) Moench. (TA)

Lolium rigidum Gaud. (R)

Poa bulbosa L. (R)

Vulpia alopecuros Schousboe. (R)

Polygonaceae

Rumex bucephalophorus L. (TR)

Polypodiaceae

Notholaena vellea (Aiton) Desv. (TR)

Primulaceae

Anagallis arvensis L. (A)

Ranunculaceae

Clematis cirrhosa L. (R)

Ranunculus paludosus Poiret. (R)

Resedaceae

Reseda alba L. (TR)

Rhamnaceae

Rhamnus oleoides L. (TR)

Zizyphus lotus (L) Lam. (TR)

Rosaceae

Crataegus monogyna L. (TR)

Rosa canina L. (TR)

Rubiaceae

Galium mollugo L. (TR)

Galium parisiense L. (TR)

Rubia peregrina L. (R)

Rutaceae

Ruta chalepensis L. (R)

Santalaceae

Osyris lanceolata Hochst. \& Steude (A)

Smilacaceae

Smilax aspera L. (R)

Tamaricaceae

Tamarix africana Poir. (TR)

Urticaceae

Parietaria mauritanica Durieu (TR)

Urtica dioica L. (A)

Verbenaceae

Vitex agnus-castus L. (TR)

Vitaceae

Vitis vinifera L. (TR) 


\section{Discussion}

Our current catalogue contains 143 taxa, representing 3\% of the Moroccan flora (Benabid, 2000).

Further analysis demonstrates the presence of 54 families, which represents $40 \%$ of the 135 vascular flora families of Morocco (Benabid, 2000).

In fact, three families constituted $36 \%$ of all the species; Asteraceae with $16 \%$, Poaceae with $11 \%$ and Fabaceae with 9\%. Figure 2 shows the proportions of the highly represented families in the area. For better clarity, the underlined families are those that constitute more than $2 \%$ of total species.

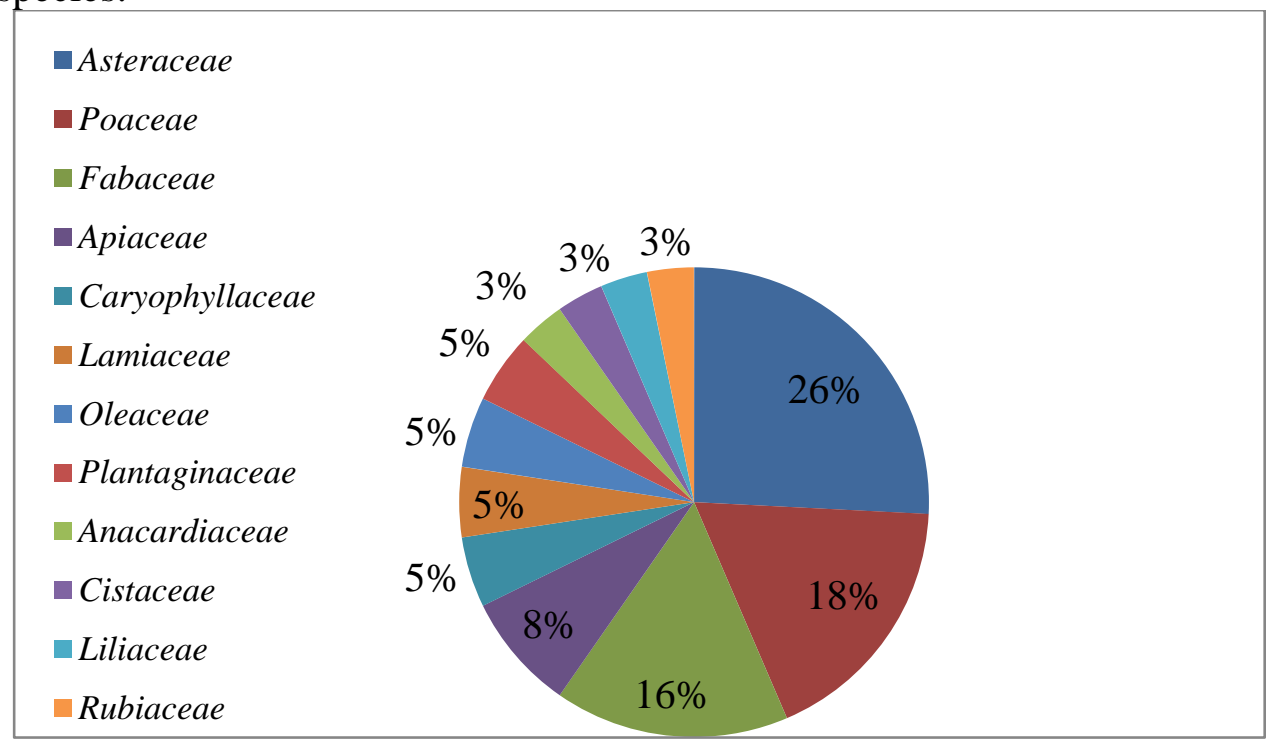

Fig 2: Proportions of the highly represented families in the SBEI of Kharouba

We registered 123 genera, representing 13\% of a total of 940 of the Moroccain flora (Benabid, 2000). The highest proportions among those in the SBEI are: Cerastium, Cistus, Eryngium, Leontodon and Plantago with 3 species for each genus.

Unfortunately, this remarkable biodiversity is on continuous depletion. Indeed, $72 \%$ of the taxa are rare to very rare and on the brink of extinction. The loss of this biodiversity is mainly due to the anthropozoogene pressure resulting in illegal woodcutting and the growing demand of needs in fodder units. In fact, the overgrazing coefficient is estimated at $49 \%$; meaning an actual animal loading two times higher than the balance load.

According to Raunkiaer's classification (1905), based on the position of perennating buds in relation to the soil surface, the SBEI flora is marked by a high representativeness of Therophytes with $41 \%$ (Figure 3), which are indicators of a major aridity and further degradation of Tetraclinis articulata 
(Vahl.) Masters ecosystem. These results also display that the decreasing aridity leads to accentuate the Geophytes and Chamaephytes tendency to dominate the field, covering respectively 10 and $9 \%$ of the flora.

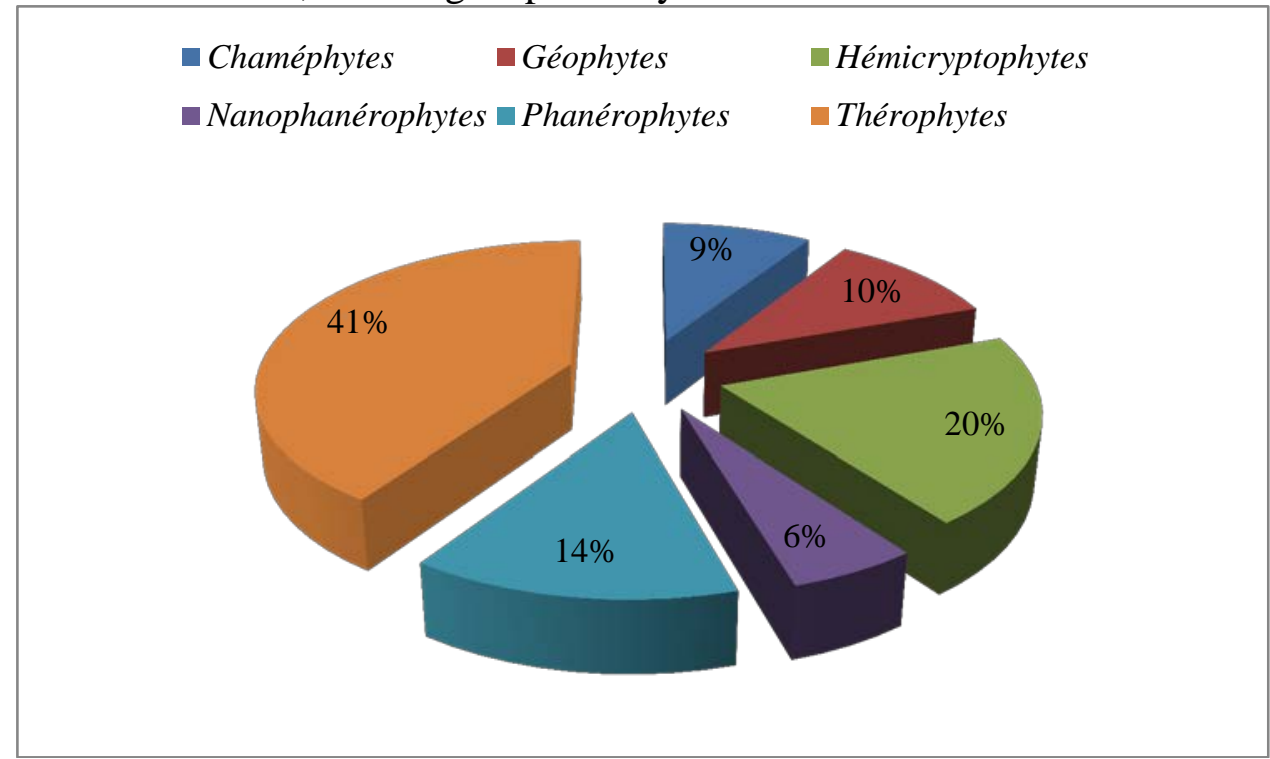

Fig 3: Biological spectrum of SBEI of Kharouba

As for Nanophanerophytes and Phanerophytes, they exhibit low percentages, due to plant formations homogenity in this study. The Phanerophytes percentage is limited and does not exceed 14\%. At variance, the Tetraclinis articulata (Vahl.) Masters is widely dominant and faces competition with the other tree species only when the environmental conditions are less favorable.

\section{Conclusion}

This study of the vascular flora of the SBEI of Kharouba led to the elaboration of a floristic catalog, the highlight of the richness and flora diversity, the evaluation of the biological spectrum of this area characterized by a significant abundance of Therophytes.

Moreover, this work has helped to demonstrate the dominance of rare taxa, illustrating the SBEI loss of biodiversity, mainly because of the constant growth of anthropozoogene pressure resulting in illegal woodcutting and overgrazing. 


\section{References:}

AFM, (Administration Forestière du Maroc) (1996). Plan National des Aires protégées. HCEFLCD, Rabat, Maroc.

Benabid, A. (2000). Flore et écosystèmes du Maroc: Evaluation et préservation de la biodiversité. Ibis Press, Paris, 357 p.

Braun-Blanquet, J. (1932). Plant sociology: the study of plant communities. McGraw-Hill, New York, NY, USA, 430 pp.

Greuter, W., Burdet, H. \& Long, G. (1984, 1986, 1989). Med-Checklist. Vols 1,2 \& 4. Geneva/Berlin Conservatoire et Jardin botanique de la Ville Genève/ Botanischer Garten \& Botanisches Museum Berlin-Dahlem.

Jahandiez, E. \& Maire, R. (1931, 1932, 1934). Catalogue des plantes du Maroc. 3 tomes, Editions Lechevalier, Paris, 913 p.

MCEF, (Ministère Chargé des Eaux et Forêts) (2002). Procès-Verbal d'aménagement de la forêt d'Ait Hatem. Vol. 1, 131 p.

McNeill, J., Barrie, F. R., Buck, W. R., Demoulin, V., Greuter, W., Hawksworth, D. L., Herendeen, P. S., Knapp, S., Marhold, K., Prado, J., Prud'homme Van Reine, W. F., Smith, G. F., Wiersema, J. H. \& Turland, N. J., eds (2012). International Code of Nomenclature for algae, fungi and plants (Melbourne Code) adopted by the Eighteenth International Botanical Congress Melbourne, Australia, July 2011. Regnum Vegetabile 154. Koeltz Scientific Books, Germany.

Tutin, T.G., Heywood, V.H., Burges, N.A., Moore, D.M., Valentine, D.H., Walters, S.M. \& Webb D.A. (1964- 1980). Flora Europaea, 1-5. 1st Edition, Cambridge University Press, Cambridge, 464, 455, 370, 523, 467 p. 